Aim of the study: The technological progress that is currently being witnessed in the areas of diagnostic imaging, treatment planning systems and therapeutic equipment has caused radiotherapy to become a high-tech and interdisciplinary domain involving staff of various backgrounds. This allows steady improvement in therapy results, but at the same time makes the diagnostic, imaging and therapeutic processes more complex and complicated, requiring every stage of those processes to be planned, organized, controlled and improved so as to assure high quality of services provided. The aim of this paper is to present clinical quality standards for radiotherapy as developed by the author.

Material and methods: In order to develop the quality standards, a comparative analysis was performed between European and Polish legal acts adopted in the period of 1980-2006 and the universal industrial ISO 9001:2008 standard, defining requirements for quality management systems, and relevant articles published in 1984-2009 were reviewed, including applicable guidelines and recommendations of American, international, European and Polish bodies, such as the American Association of Physicists in Medicine (AAPM), the European Society for Radiotherapy \& Oncology (ESTRO), the International Atomic Energy Agency (IAEA), and the Organisation of European Cancer Institutes $(\mathrm{OECl})$ on quality assurance and management in radiotherapy.

Results: As a result, 352 quality standards for radiotherapy were developed and categorized into the following three groups: 1 - organizational standards; 2 - physico-technical standards and 3 - clinical standards.

Conclusion: Proposed clinical quality standards for radiotherapy can be used by any institution using ionizing radiation for medical purposes. However, standards are of value only if they are implemented, reviewed, audited and improved, and if there is a clear mechanism in place to monitor and address failure to meet agreed standards.

\section{Clinical quality standards for radiotherapy}

\section{Marta Bogusz-Czerniewicz}

Greater Poland Cancer Centre, Poznań, Poland

Department of Radiation Technology, Faculty of Health Sciences, Poznan University of Medical Sciences, Poland

\section{Introduction}

At present, radiotherapy is an interdisciplinary field employing an advanced therapeutic and imaging apparatus and computerized therapy planning and simulation systems. This means that both the patient-related aspects (diagnosis, selection, treatment indication, justification, referral, planning, therapy, follow-up) and the control and measurement procedures, forming the technical part of the treatment process, should be subject to regular planning, verification and, most importantly, constant improvement [1].

While as of late, quality assurance in radiotherapy has been believed to play a key role in ensuring safe and effective treatment in the physical and technical context (efficient equipment, in vivo dosimetry, portal imaging), now a more systemic approach to quality is beginning to prevail [2-4]. This, however, calls for designing, implementing, maintaining and improving formalized quality systems or, in other words, implementing versatile quality management systems to cover all areas of activity (administrative, organizational, physical, technical and clinical) of a health care institution applying ionizing radiation for medical purposes.

\section{Aim of the study}

The aim of this study is to present clinical quality standards for radiotherapy as developed by the author.

\section{Material and methods}

Based on applicable EU directives [5-7] and Polish legal acts published in the period of 2002-2006 [8-23], Guidelines for Quality Assurance in Radiotherapy published by the World Health Organization in 1988 [24], Recommendations for a quality assurance programme in external radiotherapy published by the European Society for Radiotherapy \& Oncology (1995) [25], American Association of Physics in Medicine Report no 13. on physical aspects of quality assurance in radiation therapy (1994) [26], requirements of ISO 9001:2000 and 9001:2008 for quality management systems [27, 28], International Basic Safety Standards for Protection against Ionizing Radiation developed by the International Atomic Energy Agency (1996) [29], Guidelines for comprehensive audit of radiotherapy practice developed by the International Atomic Energy Agency (2005) [30], Clinical Assessment Guide developed by the Organization of European Cancer Institutes (2003) [31], and relevant literature review [32-85], a model of quality management system in radiotherapy was designed, including a detailed list of organizational, physical, technical and clinical standards.

This paper will be confined to clinical quality standards.

\section{Results}

The analysis of reference material resulted in the development of 352 quality standards which were categorised into the three following groups: a) organisational standards; b) physics and technical standards; c) clinical standards [86]. 
The clinical standards were divided into the following categories:

1.1. Referral for treatment/decision to treat/treatment prescription.

1.2. Therapeutic (treatment) protocol.

1.3. Interdisciplinary approach.

1.4. Communication.

1.5. Treatment planning.

1.6. Verification of treatment plan, irradiation time, radiotherapy form.

1.7. Treatment delivery.

1.8. Verification of treatment delivery.

1.9. Termination or withdrawal of treatment.

1.10. Medical accidents and radiological events.

1.11. Treatment quality control.

1.12. Radiation dose reference levels.

1.13. Documentation and records.

1.14. Follow-up.

1.15. Clinical audits.

A detailed description of the clinical standards is provided in Table 1.

\section{Conclusion}

The proposed clinical quality standards can be used in any institution employing ionizing radiation for medical purposes.
However, quality standards are of value only if implemented, regularly reviewed and improved through a quality management system functioning in the institution concerned to enable verification whether the pre-set standards are complied with.

Therefore, it is also very important that a quality management system is developed and implemented to contribute to:

a) improvement of work organization,

b) quality of service provided,

c) reduction of activity costs owing to rational material management,

d) patient-orientation,

e) reduction in the number of non-conformities and failures, and costs of their removal,

f) increased patient and staff safety through on-going control of equipment and work place; application of uniform procedures and documentation,

g) creation of a clear organisational structure with regard to the responsibility for assigned work,

h) strengthening of teamwork and cooperation between staff members and organisational units,

i) increased commitment of the staff in continuous improvement of the institution and its QMS.

Table 1. Clinical standards

\begin{tabular}{|c|c|}
\hline Category & Standard \\
\hline $\begin{array}{l}\text { Referral for treatment/decision } \\
\text { to treat/treatment prescription }\end{array}$ & $\begin{array}{l}\text { 1. Patients hospitalised in the institution shall be subjected to medical exposure for diagnostic or } \\
\text { therapeutic purposes, only when so prescribed by a medical practitioner. } \\
\text { 2. Examination or treatment involving ionizing radiation require a written referral issued by } \\
\text { a practitioner authorised to prescribe examination or treatment involving ionising radiation. } \\
\text { 3. Examinations involving ionizing radiation without doctor's referral may only be made under } \\
\text { screening projects. } \\
\text { 4. Decision to apply radiotherapy shall be based on patient interview, assessment of patient's health } \\
\text { and psychosocial status, physical and pathology examination results, cancer staging, and patient's } \\
\text { medical documentation. } \\
\text { 5. Results of diagnostic tests shall form an integral part of patient's medical documentation and } \\
\text { remain available before, during and after treatment. } \\
\text { 6. The institution shall evaluate patient's psychosocial condition and accordingly adjust its health } \\
\text { care and treatment options. } \\
\text { 7. Referral for radiotherapy shall be made in writing and duly authenticated (by signature, stamp and } \\
\text { date) by a radiation oncologist. } \\
\text { 8. Prescription for radiotherapy shall include planning target volume, gross tumour volume and } \\
\text { clinical target volume (PTV, GTV, CTV) according to the rules provided by ICRU 50, ICRU 62, and ICRU } \\
\text { 38 reports, total dose, method of fractioning, total duration of therapy, planned intervals, and } \\
\text { description of treatment techniques pursuant to applicable therapeutic protocols. } \\
\text { 9. Prescription for radiotherapy shall be forwarded to the team responsible for treatment planning } \\
\text { (medical physicist, dosimetrist, radiologic technologist) who do necessary calculations and } \\
\text { planning. } \\
\text { 10. The institution shall hold treatment waiting lists. }\end{array}$ \\
\hline $\begin{array}{l}\text { Therapeutic (treatment) } \\
\text { protocol }\end{array}$ & $\begin{array}{l}\text { 1. The institution has established, implemented and documented a therapeutic protocol describing } \\
\text { a treatment pattern for each type of therapy, tumour location and disease. } \\
\text { 2. The therapeutic protocol is consistent with the national model clinical procedures and based on } \\
\text { confirmed results of clinical, radiological or physical tests. } \\
\text { 3. The institution has indicated sources of the clinical standards it applies (own guidelines, national or } \\
\text { international guidelines, etc.). } \\
\text { 4. Patients are treated in accordance with an established therapeutic protocol; any exemptions need } \\
\text { to be accounted for and reasons recorded in patient's medical documentation (e.g. irradiation } \\
\text { sheet). } \\
\text { 5. Each therapeutic protocol provides for lowest possible exposure of healthy tissues (ALARA) and } \\
\text { protection of healthy tissues where practicable and justified. }\end{array}$ \\
\hline
\end{tabular}




\section{Interdisciplinary approach}

\section{Communication}

Treatment planning
6. The institution has implemented and documented a therapeutic protocol for radiotherapy of pregnant women pursuant to national regulations.

7. Therapeutic protocols are systematically reviewed and updated to keep in pace with the progress in medical and clinical knowledge.

8. The institution shall hold regular meetings to review therapeutic protocols.

1. The institution has put in place an interdisciplinary radiotherapy team (e.g. consultation committee in order to discuss all cases or difficult individual cases, cancer types, new treatment protocols, etc.).

2. The role and tasks of the interdisciplinary radiotherapy team have been defined and communicated at the institution.

3. The frequency of team meetings has been determined. The team shall meet on a regular basis.

4. The meetings shall be minuted.

5. The team shall make annual statements indicating the ratio of the number of discussed and reviewed cases (patients) to the total number of patients treated in a given year.

6. The team decisions concerning treatment of individual cases shall be minuted, and the minutes enclosed to patient's medical documentation.

1. Patients shall have an easy access to complete, updated and legible information concerning the institution, scope and type of services provided, type of examination and therapy, methods and stages of treatment delivery, detailed prescription (e.g. information brochures, website).

2. Prior to the beginning of therapy, patients shall be informed of the type of therapy to be delivered, course of treatment, possible complications and side effects and alternative treatment options, as well as procedures to be used before, during and after treatment (oral communication, audiovisual means [CD, DVD, VHS], brochures).

3. Patients may ask questions regarding the therapy and shall be given answers.

4. Responsible physicians shall make sure that information provided to patients and their families is well understood.

5. Patients shall give their written and informed consent to each examination and treatment (application of contrast agent, MRI, radiotherapy).

6. Patients shall give their written and informed consent to radiotherapy, before it is begun and after getting acquainted with information provided by the physician (in oral, written, audiovisual or other form) on the stage of the disease, prognosis, course of treatment, possible severe and late complications and side effects, and alternative treatment options, as well as procedures to be used before, during and after treatment.

7. Before providing information to the patient, physicians shall take a due account of patient's psychosocial conditions.

8. Patients shall confirm their consent to treatment by a legible signature in a radiotherapy consent form.

9. The radiotherapy consent form shall be an integrated part of patient's medical documentation.

10. Patients shall be informed of their rights and duties in the institution (orally or in writing).

11. Patient's rights and duties within the institution are communicated at that institution and available to both patients and staff (e.g. information boards).

12. Patients shall be informed of any non-conformities during treatment (e.g. under-exposure, overexposure).

13. Patients shall be informed of their right to make complaints, grievances or comments about the work of the institution, services provided and treatment delivered.

14. Radiation therapists shall, upon completion of radiotherapy, inform the referring physicians of the course of treatment.

15. The institution has developed and put in place a procedure for information flow between the institution and its patients and feedback from patients, in particular with regard to complaints and grievances.

16. The institution shall hold regular meetings between the therapeutic and radiotherapy teams.

1. Treatment planning shall be performed in consultation with a radiation oncologist, medical physicist, and, if possible, a radiologic technologist.

2. The planning treatment process should, to the extent possible, take into account patient's expectations (e.g. preferred time of procedure).

3. Therapy involving ionizing radiation shall be preceded by the development of a treatment plan including data necessary for proper delivery of radiation and simulation of planned radiation beams.

4. The simulation shall be recorded as an X-ray image or in a digital form.

5. Each decision to give up simulation for medical reasons only, shall be recorded in patient's medical documentation.

6. The simulations shall be made in the presence of a radiation oncologist, radiologic technologist and, if necessary, medical physicist.

7. 3D treatment planning shall include:

a) a series of CT images at intervals of no more than $10 \mathrm{~mm}$,

b) 3D representation of the target volume and critical organs,

c) treatment plan documentation in the form of Dose Volume Histograms (DVHs) in the target volume and critical organs. 
Verification of treatment plan, irradiation time, radiotherapy form
8. The institution has set rules for maximum and minimum dose in PTV and margins between CTV and PTV.

9. Treatment plans shall be validated by a radiation oncologist and planning medical physicist.

10. Treatment plan shall include instructions for patient immobilisation (if applicable).

11. Treatment plan shall include information on radiation field, as well as accessories and compensators to be used.

12. Radiation oncologist shall be responsible for marking the radiation field on patient's body and keeping the markings legible throughout the therapy.

13. All treatment plans and difficult cases shall be consulted at regular (weekly) consultation meetings.

14. The institution has defined the scope and frequency of consultation meetings. Consultation meetings shall be minuted and the minutes archived.

1. Electronic transfer of data (treatment parameters) from the SPL to a therapy machine shall be double checked.

2. The institution has defined the frequency and person responsible for controlling data transfer. Each control shall be documented and authenticated.

3. Treatment plan shall be checked no later than before the second radiation fraction.

4. Controls of radiation duration and dose shall be performed no later than before the second therapy session, except for treatments planned to take less than six days. In that case, controls shall be performed before radiation is started.

5. The institution has implemented and documented the procedure for assessment of errors and non-conformities found during the verification of treatment plans and during the radiation process, including sources of such errors/non-conformities, time (stage) of detection and their impact on radiation dose:

a) the institution has defined error/non-conformity source categories, e.g. documentation, dose calibration, treatment plan, patient position/immobilisation (EPID), medical documentation/ patient data management system, equipment breakdown, accidental error;

b) the institution has established stages for possible error/non-conformity detection, e.g. stage 1 - before treatment (fraction), stage 2 - during radiation, stage 3 - after radiation:

c) the institution shall analyse the impact of identified errors/non-conformities on potential and actual deviation of dose distribution.

6. The institution has implemented and documented a procedure for double independent check of calculated time of irradiation or number of monitor units per radiation field.

7. Controls shall be confirmed with controller's signature and date.

8. Any changes in treatment plans shall be validated by a radiation oncologist and, where procedurally required, medical physicist.

9. The following shall be checked before a treatment onset:

a) correctness and durability of tattoos,

b) correctness of recorded treatment physical parameters,

c) reproducibility of patient's positioning,

d) method of patient's immobilisation (to ensure reproducibility),

e) functional and mechanical stability,

f) unambiguous patient identification, including documentation and individual accessories used in the process of treatment (masks, shields).

1. All treatment procedures and related diagnosis shall be performed or supervised by radiation oncologists (if performed by doctors being trained in this speciality or radiologic technologists).

2. Radiotherapy procedures shall be planned and performed in such a way as to allow for outage of therapeutic apparatus causing deviation from accepted treatment standards.

3. The institution shall ensure that enough time is given for therapeutic session to be performed appropriately.

4. One therapeutic apparatus shall accommodate the maximum of five radical treatment patients within one hour.

5. Each irradiation fraction shall be preceded by patient identification, including the check-up of name, personal identification number (PESEL) or other identification numbers, date of birth, patient's photo, irradiation technique, irradiation parameters, irradiated area, tumor location, accessories used, etc.

6. At each stage of treatment, the institution shall show full respect for patients' privacy and personal data protection.

7. Patient's radiotherapy form shall be available at a given apparatus during each irradiation fraction.

8. First irradiation fraction in radical treatment patients and - in justified cases - in palliative treatment patients shall be attended by a radiation oncologist to verify patient's positioning and immobilisation, beam centring, correctness of radiation parameters and to provide patients with psychological support.

9. Medical physicist shall participate in radiation procedures at a radiation oncologist's or technologist's request.

10. Patients shall be positioned and immobilised by two radiologic technologists. 
Verification of treatment delivery

\section{Termination or withdrawal} of treatment

\section{Medical radiation accidents and incidents}

\section{Treatment quality control}

11. Patients shall be positioned and immobilised as accurately, repetitively and comfortably as possible (in each machine used in the treatment process, according to instructions contained in treatment plan (as a text or diagram).

12. In the case of radical and palliative treatment, a radiation therapist shall participate in the first irradiation session performed according to a pre-set treatment plan.

13. During radiotherapy, patients shall be monitored by a radiologic technologist (audiovisual system).

14. Radiologic technologist shall confirm the consistency of physical parameters entered into the radiotherapy form with those actually delivered, in particular monitor units (exposure time).

1. During the first fraction, a radiation oncologist shall:

a) instruct a radiologic technologist to take a portal image and verify patient's position in relation to the beam (whether the beam is well aimed at the target volume and whether OARs are outside the radiation field), according to a simulator or CT plan,

b) verify patient's positioning and immobilisation,

c) control the positioning (centring) of beams to ensure that all treatment parameters are consistent with the plan,

d) check if all beam modifiers and accessories are suited for the patient being treated and properly positioned in relation to the patient and the therapeutic machine,

e) instruct a radiologic technologist to perform in vivo dosimetry in order to check whether the dose administered is consistent with the planned one $\pm 5 \%$ (according to ICRU Report 24).

2. Any changes in treatment plans shall be authenticated by a radiation oncologist and, where procedurally required, medical physicist.

3. The institution has established a code of practice in case of any changes in a treatment plan made during therapy.

4. During treatment, a radiation oncologist shall, at least once a week, perform a control and review of: a) entries in the radiotherapy form and medical documentation,

b) patient's physical status (tolerance to therapy and radiation response),

c) correctness of treatment delivery (in vivo dosimetry, portal imaging),

d) deviation from a set radiological procedure shall each time be explained in medical documentation.

1. The institution has established a code of practice in case of therapy being interrupted or abandoned.

2. Treatment may be interrupted or abandoned by an attending or supervising physician, subject to prior consultation with a consultation committee, in cases of:

a) wrong qualification for treatment,

b) error in physical or technical radiation parameters found during treatment,

c) patient's intolerance to treatment or threat to patient's life posed by continuing therapy.

3. The institution shall have immediate access to a defibrillator set in case of a threat to patient's life and health.

4. The institution has established a code of practice in case of acute conditions occurring during therapy.

1. The institution has defined the concepts of radiological incident and accident in accordance with national legal regulations (class A or B accidents).

2. The institution has put in place and documented a code of practice for incidents or accidents related to the use of ionizing radiation in radiotherapy and detailed rules for prevention of such accidents.

3. The institution shall document all radiation incidents or accidents and any corrective and protective measures taken in response to such events.

4. The institution has established rules for informing victims of radiological incidents and accidents of such events, their side effects and possible complications.

5. Patients who are victims of radiation incidents or accidents shall, if necessary, be subjected to appropriate examination or treatment.

1. Treatment quality control shall include the verification of:

a) treatment physical parameters (dose, dose distribution, irradiation time),

b) reproducibility of patient's positioning,

c) method of patient's immobilisation (to ensure reproducibility),

d) functional and mechanical stability,

e) unambiguous patient identification, including documentation and individual accessories used in the process of treatment (masks, shields),

f) correctness of treatment plan delivery (in vivo dosimetry, portal imaging),

g) correctness of records made in the course of the treatment process (patient data),

h) correctness of the recording and transfer of data and instructions between various stages, such as treatment planning (SPL), simulation, irradiation, and entries in medical documentation (medication log, radiotherapy form),

i) patient's health status (tolerance to therapy, radiation response, therapy side effects). 
2. All stages of control shall be performed by independent professionals with no direct involvement in the activity controlled (e.g. treatment plans should be verified by a medical physicist not being a member of the planning team).

3. The institution shall periodically and systematically analyse results of in-vivo dosimetry and portal imaging.

Radiation dose reference levels

\section{Documentation and records}

The institution has established and documented radiation dose reference levels for $\mathrm{X}$-ray examination in accordance with the national law (Annex 1 to the Regulation of 25 August 2005).

1. All activities, from patient's admission to discharge, including follow-up, shall be clearly defined, described and recorded in patient's medical documentation.

2. The institution has implemented and documented a procedure for supervising medical records, specifying, among other things, how they should be made (electronically, on paper, plates, films, etc.) and stored, as well as period and place of storage.

3. Period of storage shall comply with national requirements in this area.

4. The institution shall register:

a) patient's medical history,

b) identified risk factors,

c) patient's general health status,

d) results of physical examination,

e) clinical stage of disease in line with adopted classification system (e.g. UICC) or staging method (e.g. FIGO),

f) for patients treated previously, description of techniques used, direct outcome and evaluation of effects (e.g. leukopenia, impotence, nerve paralysis, etc.),

g) diagnostic examination results,

h) histopathology results. If treatment is delivered without histopathologic confirmation, the institution shall document rationale for treatment (e.g. certain lesions in the brain unattainable for biopsy),

i) purpose of treatment (e.g. curative, adjuvant, palliative, alleviating pain),

j) referral for treatment containing:

- patient's name and date of birth,

- aim and reasons for examination or treatment,

- preliminary clinical diagnosis,

- information necessary for proper performance of radiological procedure,

k) patient's treatment plan (patient measurements, radiation parameters, anatomical description of the target volume (as defined by ICRU 38 or ICRU 50 and 62),

l) treatment summary.

5. A radiotherapy form shall include:

a) unambiguous patient identification and diagnosis,

b) name of an attending doctor and, in his or her temporary absence, name of a substitute doctor, and a supervising doctor (should the attending doctor be not a radiation oncologist),

c) readable, unambiguous and duly signed doctor's prescription to deliver radiation including:

- patient's medical exposure physical parameters and information enabling reproduction of patient's position on the treatment couch,

- fractionated doses to the target volume for each radiation field (or total dose to all radiation fields),

- time interval between successive fractions,

- total dose and method used to record the cumulative dose,

- for each radiation sensitive organ with dose histogram calculated, dose value shall be set, based on which, according to the therapeutic procedure used, the risk of late post-radiation damage is assessed; organs with no histogram calculated shall be assigned a maximum dose,

- beam modifiers used (shields, filters, compensators) and their corresponding radiation fields, including methods of use.

6. At the end of treatment, patients shall receive discharge information including prescription for further conduct, care, diet, etc.

7. On patient's written request, the institution shall provide the patient with copies of his or her medical records.

8. Copies of discharge information are stored in patient's medical documentation.

9. All medical records and documents produced during treatment make it possible to reconstruct and track down complete datasets on patients, clinical information and treatment modalities.

10. Medical documentation (all records made - referral, medication log, treatment plan, etc.) shall be authenticated by a signature and stamp of persons responsible for entering particular data.

11. Medical documentation (radiotherapy form, treatment plan) shall be subject to periodical and systematic review at least:

a) before the start of treatment, after one fraction at the latest,

b) daily, by a radiologic technologist,

c) weekly, by a radiation oncologist and medical physicist (radiation parameters),

d) at each modification of a treatment plan or new radiation field,

e) upon completion of treatment. 
12. Radiotherapy form shall be checked no less than once a week throughout the treatment period for correctness of doses administered to patients. The following shall be subject to detailed control: a) total doses absorbed by patients,

b) compliance of radiotherapy form entries with treatment plan, including with regard to radiation regularity.

13. Data included in radiotherapy forms shall be controlled by authorised persons, their competences specified in the Quality Management System in Radiotherapy.

14. Controls shall be documented.

15. Committee for QMS in Radiotherapy has established and put in place a procedure for review of medical documentation, including:

a) scope of review,

b) responsibility,

c) frequency,

d) definitions for low-risk errors,

e) definitions for high-risk errors

f) stages of conduct in case of identified errors or non-conformities,

g) periodical and systematic review of identified errors or non-conformities by the Committee for QMS in Radiotherapy,

h) periodical and systematic review of corrective and preventive measures taken.

16. Each documentation check shall be authenticated (controller's signature and date).

17. The institution shall fix the mean duration for particular treatment stages (e.g. imaging, treatment planning, simulation, irradiation, making of standard and customised masks, etc.) and maximum permissible waiting time.

18. Medical services involving ionizing radiation shall only be provided based on documented procedures.

19. The institution has established and implemented working and radiological procedures according to the national model procedures for all teleradiotherapy techniques applied, in particular for conformal teletherapy, radical teletherapy with 3D planning, radical teletherapy with 2D planning, palliative, and stereotactic teletherapy.

20. The institution has implemented and documented:

a) a procedure for treatment involving ionizing radiation specifying:

- methods for qualifying patients for treatment,

- planning and simulation,

- course of radiotherapy,

- course of follow-up,

- rules for replacing a therapeutic apparatus, in case of technical failure during radiotherapy, including conversion and check of treatment parameters,

b) procedure for referring patients for treatment,

c) procedure for priority admissions (decision to admit patients out of turn shall be taken on a collegial basis by two specialist physicians and recorded in patient registration documents),

d) report checking dose by measurement of in vivo dosimetry,

e) verification report of correct patient positioning in relation to the beam by a portal image.

21. All procedures, instructions and records shall be periodically and systematically reviewed (at least once a year) and updated if necessary.

22. Documentation updates are authorized, dated and numbered.

23. Archival copies shall be held exclusively by the Representative for QMS in Radiotherapy.

24. The institution has put in place a detailed code of practice for persons who, on a free and voluntary basis, provide support and take care of patients subjected to medical exposure.

25. The institution has implemented and documented a code of practice in case of patient medical documentation being lost.

1. After completion of therapy, all patients shall be covered with regular follow-up performed by radiation oncologists.

2. The institution shall set the frequency of follow-up examinations for patients treated radically and palliatively, and if recommended for particular cases.

3. Follow-up should be systematic and consistent with the pre-set schedule.

4. Results of follow-up examinations shall be recorded in patient's medical documentation.

5. Side effects (radiation response) shall be recorded using scoring systems for particular organs and tissues.

6. Treatment outcomes shall be regularly evaluated by physicians, radiotherapy team and internal clinical auditors.

Clinical audits

1. The institution shall carry out, on a written request from the head of the institution, annual internal clinical audits.

2. Head of the institution shall appoint an auditing team to perform the internal clinical audit consisting of a radiation therapist, medical physicist and, if necessary, a medical engineer.

3. Internal and external clinical audits shall focus on patients and their treatment process from diagnosis, through decision to treat, referral for treatment, prescription, planning, therapy preparation and delivery, to follow-up. 


\section{References}

1. Bogusz-Osawa M, Kosicka G. Istota wdrożenia programu za pewnienia jakości bezpiecznego napromieniania podczas radioterapii megawoltowej. Zdr Zarz 2002; 4: 67-71

2. Bogusz-Osawa M, Osawa T. The influence of the European and Polish act of law, regulations and standards on the forms and the contents of the informed consent for oncological treatments. Rep Pract Oncol Radiother 2005; 10: 67-76.

3. Grönroos Ch. Service Management and Marketing. Lexington Books, Lexington 1990.

4. Nowotarska-Romaniak B: Marketing usług zdrowotnych. Zakamycze, Kraków 2002.

5. Dyrektywa Rady 90/641/Euratom z dnia 04.12.1990 w sprawie prak tycznej ochrony pracowników zewnętrznych, narażonych na promieniowanie jonizujące podczas pracy na terenie kontrolowanym. Dziennik Urzędowy L-349 z 0513/12/90.

6. Dyrektywa Rady 96/29/EURATOM z dnia 13 maja 1996 ustanawiająca podstawowe normy bezpieczeństwa w zakresie ochrony zdrowia pracowników i ogółu społeczeństwa przed zagrożeniami wynikającymi z promieniowania jonizującego. Dziennik Urzędowy L-159 z 29/06/96.

7. Dyrektywa Rady 97/43/Euratom z dnia 30.06.1997 w sprawie ochrony zdrowia osób fizycznych przed niebezpieczeństwem wy nikającym z promieniowania jonizującego związanego z badaniami medycznymi oraz uchylająca dyrektywę 84/466/Euratom. Dziennik Urzędowy L-180 z 09/07/97.

8. Rozporządzenie Ministra Pracy i Polityki Społecznej z dnia 29.11.2002 r. w sprawie najwyższych dopuszczalnych stężeń i natężeń czynników szkodliwych dla zdrowia w środowisku pracy. Dz.U. Nr 217, poz. 1833

9. Rozporządzenie Ministra Zdrowia z dnia 7 kwietnia 2006 r. w sprawie minimalnych wymagań dla zakładów opieki zdrowotnej ubie gających się o wydanie zgody na prowadzenie działalności związane z narażeniem na promieniowanie jonizujące w celach medycznych, polegającej na udzielaniu świadczeń zdrowotnych z zakresu radioterapii onkologicznej. Dz.U. Nr 75, poz. 528.

10. Rozporządzenie MZ z dnia 24.12.2002 r. w sprawie warunków bez piecznego stosowania promieniowania jonizujacego w celach medycznych oraz sposobu wykonywania kontroli wewnętrznej nad przestrzeganiem tych warunków. Dz.U. Nr 241, poz. 2098.

11. Rozporządzenie MZ z dnia 25.08.2005 w sprawie warunków bez piecznego stosowania promieniowania jonizującego dla wszystkich rodzajów ekspozycji medycznej, na podstawie art. 33c ust. 9 ustawy z dnia 29.11.2000 - Prawo Atomowe Dz.U. z 2004 r. Nr 61, poz. 1689 i Nr 173, poz. 1808

12. Rozporządzenie Rady Ministrów z dn. 18.01.2005 r. w sprawie pla nów postępowania awaryjnego w przypadku zdarzeń radiacyjnych. Dz.U. Nr 20, poz. 169.

13. Rozporządzenie Rady Ministrów z dnia 03.12.2002 r. w sprawie dokumentów wymaganych przy składaniu wniosku o wydanie ze zwolenia na wykonywanie działalności związanej z narażeniem na działanie promieniowania jonizującego albo przy zgłoszeniu wy konywania tej działalności. Dz. U. Nr 220, poz. 1851 z późn. zm. z dnia 27.04.2004 r.

14. Rozporządzenie Rady Ministrów z dnia 03.12.2002 r. w sprawie odpadów promieniotwórczych i wypalonego paliwa jądrowego. Dz.U. Nr 230, poz. 1925

15. Rozporządzenie Rady Ministrów z dnia 05.11.2002 r. w sprawie wymagań dotyczących rejestracji dawek indywidualnych. Dz. U. Nr 207, poz. 1753.

16. Rozporządzenie Rady Ministrów z dnia 06.08.2002 r. w sprawie podstawowych wymagań dotyczących terenów kontrolowanych i nad zorowanych. Dz.U. Nr 138, poz. 1161

17. Rozporządzenie Rady Ministrów z dnia 06.08.2002 r. w sprawie rodzajów stanowisk mających istotne znaczenie dla zapewnienia bez pieczeństwa jądrowego i ochrony radiologicznej szczegółowych warunków i trybu nadawania uprawnień dla osób, które mogą być zatrudnione na tych stanowiskach. Dz. U. Nr 145 poz. 1217, znowelizowane 18.01.2005 r., Dz. U. Nr 21 poz. 176.

18. Rozporzadzenie Rady Ministrów z dnia 17.12.2002 r. w sprawie szczegółowych warunków bezpiecznej pracy ze źródłami promieniowa nia jonizującego. Dz. U. Nr 239 poz. 2029.

19. Rozporządzenie Rady Ministrów z dnia 23.12.2002 r. w sprawie wymagań dotyczących sprzętu dozymetrycznego Dz. U. Nr 239, poz. 2032.
20. Rozporzadzenie Rady Ministrów z dnia 28.05.2002 r. w sprawie dawek granicznych promieniowania jonizującego 03.08.2002. Dz.U. Nr 111, poz. 969 z późn. zm. z dnia 18.01.2005 r.

21. Ustawa Prawo Atomowe z dnia 29.11.2000 r. Dz.U. z 2001 r. Nr 3, poz.18.

22. Ustawa Prawo Atomowe z dnia 12.03.2004 r. Dz.U. z 2004 r. Nr 70, poz. 632.

23. Ustawa Prawo Atomowe z dnia 24 lutego 2006 r. Dz.U. z 2006 r. Nr 52, poz. 378.

24. World Health Organization (WHO). Quality Assurance in Radiotherapy. Geneva, WHO, 1988.

25. Aletti P, Bey P. Recommendations for a quality assurance programme in external radiotherapy. ESTRO Booklet No. 2. Apeldoorn Garant, Leuven 1995.

26. American Association of Physics in Medicine (AAPM). Report no 13. Physical aspects of quality assurance in radiation therapy. New York, American Institute of Physics, 1994, [63 pp. screens]. Available at: http://www.aapm.org/pubs/reports/rpt_13.pdf.

27. Polski Komitet Normalizacyjny (PKN). PN-EN ISO 9001:2000 System Zarządzania Jakością - Wymagania. PKN, Warszawa 2001.

28. Polski Komitet Normalizacyjny (PKN). PN-EN ISO 9001:2008 System Zarządzania Jakością - Wymagania. PKN, Warszawa 2009.

29. International Atomic Energy Agency (IAEA). International Basic Safety Standards for Protection against Ionizing Radiation and for the Safety of Radiation Sources, Safety series No. 115. IAEA, Vienna 1996.

30. International Atomic Energy Agency (IAEA). Guidelines for comprehensive audit of radiotherapy practice: a tool for quality improvement - workshop materials, QUATRO. IAEA, Vienna 2005.

31. Organization of European Cancer Institutes (OECI). Clinical Assessment Guide, Preliminary document, Version 0. OECI, 2004.

32. American Association of Physics in Medicine (AAPM). Report no 1. Phantoms and performance evaluation and quality assurance of CT scanners. Chicago, American Institute of Physics, 1977, [27 pp. screens]. Available at: http://www.aapm.org/pubs/reports/rpt 01.pdf.

33. American Collage of Radiation Oncology (ACRO). Standards for Radiation Oncology. [11 pp. screens]. Available at: http://www.acro.org/ content/internet_resources/acro_practice_accreditation/radiation standards.cfm.

34. Nath R, Biggs PJ, Bova FJ, Ling CC, Purdy JA, van de Geijn J, Weinhous MS. AAPM code of practice for radiotherapy accelerators. Med Phys 1994; 21: 1093-121.

35. Asch DV. Waiting times for cancer treatment. Clin Oncol 2000; 12: 140. 36. Barthelemy-Brichant N, Sabatier J, Dewé W, et al. Evaluation of frequency and type of errors detected by a computerized record and verify system during radiation treatment. Radiother Oncol 1999; 53: 149-54.

37. Belletti S, Dutreix A, Garavaglia G, et al. Quality assurance in radiotherapy: importance of medical physics staffing levels. Recommendations from an ESTRO/EFOMP join task group. Radiother Oncol 1996; 41: 89-94.

38. Bentzen SM, Heeren G, Cottier B, et al. Towards evidence-based guidelines for radiotherapy infrastructure and staffing needs in Europe: the ESTRO QUARTS Project. Radiother Oncol 2005; 75: 355-65.

39. Bernier J, Horiot JC, Bartelink H, Johansson KA, Cionini L, Gonzaléz Gonzaléz D, Hamers H, van den Bogaert W. Profile of radiotherapy departments contributing to the cooperative group pf the European Organization for Research and Treatment of Cancer. Radiat Oncol Biol Phys 1996; 34: 965-7.

40. Bernier J, Horiot JC, Poortmans P. Quality Assurance in radiotherapy: form radiation physics to patient-and trial-oriented control procedures. Eur J Cancer 2002; 38: S155-8.

41. Bleehen NM. Ouality assurance in radiotherapy. Report of standing sub-committee on Cancer. Department of Health, London 1991.

42. Bogusz-Osawa M, Kierzkowski J, Kubicka M. Wskazania praktyczne w zakresie wdrażania programu zapewnienia jakości w radioterapii - procedury w zakresie ochrony radiologicznej. Wspolczesna Onkol 2002; 8: 506-14

43. Bogusz-Osawa M. Standardy akredytacyjne a opieka pielęgniarska - aspekty organizacyjne i praktyczne. Antidotum Zarz Op Zdr 2002; 9: 41-7.

44. Burnett D. A practical guide to accreditation in laboratory medicine. KSC Printers, Tunbridge Wells 2002. 
45. Calandrino R, Cattaneo GM, Fiorino C, Longobardi B, Mangili P, Signorotto $P$. Detection of systematic errors in external radiotherapy before treatment delivery. Radiother Oncol 1997; 45: 271-4.

46. Calandrino R, Cattaneo GM, Del Vecchio A, et al. Human errors in the calculation of monitor units in clinical radiotherapy practice. Radiother Oncol 1993; 28: 86-8.

47. Crosby PB. Quality is free. Free Press, New York 1979.

48. Dische S, Saunders MI, Williams C, Hopkins A, Aird E. Precision in reporting the dose given in a course of radiotherapy. Radiother Oncol 1993; 29: 287-93.

49. Duggan L, Kron T, Howlett S, Skov A, O'Brien P. An independent check of treatment plan, prescription and dose calculation as a QA procedure. Radiother Oncol 1997; 42: 297-301.

50. Society for Therapeutic Oncology and Radiology (ESTRO). Executive Summary. ESQUIRE Project: Education, Science and Quality assurance in Radiotherapy in Europe, Grant Agreement/2001CVGG2 005 EC/ February 2003. [5 pp. screens]. Available at: http://www.estroweb.org/ESTRO/upload/pdfs/Esquirelyear1ExecutiveSummary.pdf.

51. Feigenbaum AV. Total Quality Control. McGraw-Hill Cooperation, New York 1992

52. Ferreira IH, Dutreix A, Bridier A, et al. Radiotherapy dosimetry audit: a European programme to improve quality and safety in radiation treatments. Proceedings of the International Conference on the Radiological Protection of Patients in Diagnostic and Interventional Radiology, Nuclear Medicine and Radiotherapy; 2001 Mar 26-30; Malaga, Spain. IAEA, Vienna 2001.

53. International Atomic Energy Agency (IAEA). Safety Report Series No. 17: Lessons learned from accidental exposures in radiotherapy. IAEA, Vienna 2000

54. Ito H, Iwasaki S, Nakano Y, et al. Direction of quality improvement activities of health care organizations in Japan. Int J Qual Health Care 1998; 10: 361-3.

55. Izewska J, Andreo P. The IAEA/WHO TLD postal program for radio therapy hospitals. Radiother Oncol 2000; 54: 65-72.

56. Karzmark CJ. Procedure and operator error aspects of radiation accidents in radiotherapy. Int I Radiat Oncol Biol Phys 1987; 12: 1599-602.

57. Kolitsi Z, Dahl O, Van Loon R, Drouard J, Van Dijk J, Ruden BI, Chierego G, Rosenwald JC. Quality assurance in conformal radiotherapy: DYNARD consensus report on practice guidelines. Radiother Oncol 1997; 45: 217-23.

58. Kutcher GJ, Coia L, Gillin M, et al. AAPM, American Association of Physicists in Medicine. Comprehensive QA for radiation oncology. Report of AAPM Radiation Therapy Committee Task Group 40. Med Phys 1994; 21: 581-618

59. Leer JW, Corver R, Kraus JJ, vd Togt JC, Buruma OJ. A quality assurance system based on ISO Standards: experience in a radiothera py Department. Radiother Oncol 1995; 35: 75-81.

60. Leer JW, McKenzie A, Scalliet P, et al. Practical guidelines for the implementation of a quality system in radiotherapy. A project of the ESTRO Quality Assurance Committee, sponsored by Europe Against Cancer, Physics for Clinical Radiotherapy. Booklet No. 4. ESTRO, Brussels 1998.

61. Leunens G, Verstraete J, Van den Bogaert W, Van Dam J, Dutreix A, van der Schueren E. Human errors in data transfer during the preparation and delivery of radiation treatment affecting the final result: "garbage in, garbage out". Radiother Oncol 1992; 23: 217-22.

62. Malicki J, Litoborski M, Kierzkowski J, Kosicka G. How the implementation of in-vivo dosimetry protocol improved the dose delivery accuracy in head and neck radiotherapy. Neoplasma 2004; 51: 155-8.

63. Martin CJ, Sutton DG. Practical radiation protection in health care. Oxford University Press, New York 2002.

64. McKenzie AL. Would the two most serious radiotherapy accidents in the UK have occurred under ISO 9000? In: Radiation Incidents. Faulkner K, Harrison RM (eds.). British Institute of Radiology, London 1996.

65. McNee SG. Clinical governance: risks and quality control in radiotherapy. Br J Radiol 2001; 74: 209-12.

66. Meunier F, van Oosterom AT. 40 years of EORTC; the evolution towards a unique network to develop new standards of cancer care. Eur J Cancer 2002; 38: S155-8.

67. Nolan TW. System changes to improve patient safety. BMJ 2000; 320: 771-3.
68. Proceeding on the Symposium, International Symposium on Prac tical Implementation of Clinical Audit for Exposure to Radiation in Medical Practice; 2003 May 24-27; Tempere, Finland.

69. Radiation and Nuclear Safety Authority (STUK). Quality Assurance in Radiotherapy. STUK Guide ST 2.1/22 May 2003. Helsinki, STUK, 2003. Available at: http//www.finlex.fi/pdf/normit/22197-ST2-1e.pdf.

70. Reason J. Human error: models and management. BMJ 2000; 320: 768-70.

71. Schwappach D, Koeck Ch. What makes an error unacceptable? A factorial survey on the disclosure of medical errors. Int I Qual Health Care 2004; 16: 317-26.

72. Slotman BJ, Cottier B, Bentzen S, et al. Guidelines for infrastructure and staffing of radiotherapy, ESTRO-QUARTS: Work package 1, 27 06-2004, BSL. ESTRO, Brussels 2004

73. Slotman BJ, Cottier B, Bentzen SM, Heeren G, Lievens Y, van den Bogaert W. Overview of national guidelines for infrastructure and staffing of radiotherapy. ESTRO-OUARTS: Work package 1. Radiother Oncol 2005; 75: 349-54.

74. Sweeney J, Heaton C. Interpretations and variations of ISO 9000 in acute health care. Int J Qual Health Care 2000; 12: 203-9.

75. Teunen D. The European Directive on health protection of individuals against the dangers of ionizing radiation in relation to medical exposure (97/43/Euratom). J Radiol Prot 1998; 18: 133-7.

76. The Netherlands Organization for Applied Scientific Research (TNO). Quality Assurance Standards, Report on the PACE project. TNO, Leiden 1994.

77. Thompson RE. From quality assurance to continuous improvement. The Phys Exec 1992; 17: 3-8.

78. Thwaites D. Quality Assurance into the next century. Radiother Oncol 2000; 54: vii-ix.

79. Thwaites D, Scalliet P, Leer JW, Overgaard J. Quality assurance in radiotherapy. European Society for Therapeutic Radiology and Oncology Advisory Report to the Commission of the European Union for the "Europe Against Cancer Programme". Radiother Oncol 1995; 35: 61-73.

80. Valli MC, Prina M, Bossi A, et al. Evaluation of most frequent errors in daily compilation and use of a radiation treatment chart. Radiother Oncol 1994; 32: 87-9.

81. Van der Scheuren E, Horiot JC, Leunnens G, et al. Quality assurance in cancer treatment. Eur J Cancer 1993; 29A: 172-81.

82. Van Esch A, Bogaerts R, Kutcher, GJ, et al. Quality assurance in radiotherapy by identifying standards and monitoring treatment preparations. Radiother Oncol 2000; 56: 109-15.

83. Van Weert C. Developments in professional quality assurance towards quality improvement: some examples of peer review in the Netherlands and the United Kingdom. Int J Qual Health Care 2000; 12: 239-42.

84. Clinical risk management: enhancing patient safety. Vincent Ch (eds.) BMJ Books, London 2001.

85. Weinberg N, Stason WB. Managing quality in hospital practice. Int J Qual Health Care 1998; 10: 295-302.

86. Bogusz-Czerniewicz M. System Zarządzania Jakością w Radioterapii. Wymagania prawne krajowe i unijne, model, standardy, dokumentacja, instrukcje wdrożenia na przykładzie Wielkopolskiego Centrum Onkologii. Wyd. Uniwersytetu Medycznego im. K. Marcinkowskiego, Poznań 2010.

87. Kowalik A, Konstanty E. Basic tests in mammography as a tool in quality improvement. Rep Pract Oncol Radiother 2010; 15: 145-5288.

88. Blecharz P, Urbański K, Reinfuss M, Szatkowski W, Jasiówka M. Radioterapia i chemioterapia chorych na pierwotnego inwazyjnego raka pochwy. Wspolczesna Onkol 2010; 14: 265-9.

\section{Address for correspondence}

\section{Marta Bogusz-Czerniejewska}

Wielkopolskie Centrum Onkologii

ul. Garbary 15

61-866 Poznań

e-mail: martabogusz@wco.pl

\section{Submitted: $\quad 25.06 .2010$ \\ Accepted: $\quad$ 18.01.2012}

